\title{
Correction to: PF-06438179/GP1111: An Infliximab Biosimilar
}

\author{
Zaina T. Al-Salama ${ }^{1}$
}

Published online: 15 November 2018

(c) Springer Nature 2018

\section{Correction to: BioDrugs https://doi.org/10.1007/s40259-018-0310-5}

The article PF-06438179/GP1111: An Infliximab Biosimilar, written by Zaina T. Al-Salama, was originally published Online First without open access. After publication online, HEXAL AG requested that the article be Open Choice to make the article an open access publication. Post-publication open access was funded by HEXAL AG. The article is forthwith distributed under the terms of the Creative Commons Attribution-NonCommercial 4.0 International License (http://creativecommons.org/licenses/by-nc/4.0/), which permits any noncommercial use, duplication, adaptation, distribution and reproduction in any medium or format, as long as you give appropriate credit to the original author(s) and the source, provide a link to the Creative Commons license and indicate if changes were made.

The original article has been corrected.

Open Access This article is distributed under the terms of the Creative Commons Attribution-NonCommercial 4.0 International License (http://creativecommons.org/licenses/by-nc/4.0/), which permits any noncommercial use, distribution, and reproduction in any medium, provided you give appropriate credit to the original author(s) and the source, provide a link to the Creative Commons license, and indicate if changes were made.

The original article can be found online at https://doi.org/10.1007/ s40259-018-0310-5.

Zaina T. Al-Salama

demail@springer.com

1 Springer, Private Bag 65901, Mairangi Bay, Auckland 0754, New Zealand 